\title{
PEMIKIRAN IMAM AL-ZARNUJI TENTANG PENDIDIKAN DAN RELEVANSINYA DENGAN PENDIDIKAN MODERN
}

\author{
Khusna Farida Shilviana \\ Universitas Islam Negeri Sunan Kalijaga Yogyakarta \\ Email: 19402010010@student.uin-suka.ac.id
}

\begin{abstract}
Abstrak
Pendidikan Islam diharapkan mampu untuk membentuk peserta didik yang mampu menerapkan nilai-nilai spiritual religius dan juga etika, namun yang terjadi belum mencapai apa yang ditargetkan. Sebagai solusi perlu adanya pembaharuan dalam konsep pendidikan. Penulisan makalah ini menggunakan metode studi pustaka (library research) yaitu menemukan, dan menganalisis berbagai informasi terkait dengan pembahasan melalui buku, jurnal dan teks-teks yang berhubungan dengan pembahasan. Ditemukan hasil bahwa pemikiran pendidikan al-Zarnuji relevan dengan pendidikan modern, yaitu: 1) Tujuan pendidikan, relevan dari adanya kesesuaian dengan tujuan pendidikan nasional dalam UU Sisdiknas tahun 2003 tentang tujuan pendidikan, yang mana antara keduanya menekankan pada akhlak. 2) Pendidik, bisa dilihat dari kompetensi kepribadian guru, yaitu suatu kemampuan kepribadian yang mantap, berakhlak mulia, arif, dan berwibawa serta menjadi teladan bagi peserta didik. 3) peserta didik, relevan dilihat dari adanya kesesuaian dengan UU Sisdiknas nomor 23 Tahun 2003 Bab V pasal 12 bahwa peserta didik mempunyai kewajiban menjaga norma-norma Pendidikan. 4) kurikulum, bisa dilihat dari landasan dasar kurikulum Pendidikan Islam diantaranya adalah dasar agama, dan juga terdapat dasar psikologis. 5) Metode Pendidikan, bisa dilihat bahwa di era sekarang metode menghafal dan metode diskusi masih digunakan dengan tetap berdasarkan pada kebutuhan.
\end{abstract}

Kata kunci: al-Zarnuji, Pendidikan, Era Modern

\begin{abstract}
Islamic education is expected to be able to shape students who are required to be able to apply religious spiritual values and ethical, but what has not yet achieved what is targeted. As a solution there needs to be an update in the concept of education. The writing of this paper uses library research methods, namely finding and analyzing various information related to the discussion through books, journals and texts related to the discussion. It was found that the thought of al-Zarnuji's education was relevant to the modern era, namely: 1) Educational objectives, relevant from the existence of conformity with national education goals in the 2003 National Education System Law on educational goals, which between the two emphasized morals. 2) Educators, can be seen from the teacher's personal competence, which is a strong personality ability, noble, wise, and authoritative as well as an example for students. 3) students, it is relevant to be seen from the conformity with Law on National Education number
\end{abstract}


23 of 2003 Chapter V article 12 that students have an obligation to maintain the norms of education. 4) curriculum, can be seen from the basic foundation of Islamic Education curriculum including the basis of religion, and there is also a psychological basis. 5) Education Method, it can be seen that in the present era the memorization method and the discussion method are still used while still based on needs.

Keywords: al-Zarnuji, education, Modern Era

\section{A. PENDAhuluan}

Pendidikan Islam mempunyai misi yang sangat penting. Yang tidak hanya terbatas pada transfer pengetahuan yang orientasinya hanya pada kemampuan intelektual saja, tetapi lebih dari itu pendidikan Islam seharusnya juga mengantarkan kepada penerapan nilai-nilai spiritual religius dan juga etika, yang seharusnya itulah yang dijadikan prioritas dan orientasi tertinggi dalam pendidikan. Oleh karenanya, pendidikan mengenai spiritual, religius dan moralitas harus ditanamkan kepada anak-anak sejak dini.

Akan tetapi yang terjadi dilapangan, banyak peserta didik sekarang yang mengalami kemerosotan dalam moralitasnya, misalnya seperti kurang menghormati gurunya. Salah satu contohnya adalah seperti kejadian yang menimpa seorang guru disebuah sekolah SMA yang mengalami penganiayaan berujung maut oleh siswanya sendiri. Hal itu terjadi hanya karena siswa tidak terima ketika ditegur oleh gurunya ketika pelajaran berlangsung, padahal teguran itu juga karena berasal dari ulahnya sendiri (Ratna Puspita, "Mahfud MD: Guru Dianiaya Siswa Karena Runtuhnya Moral", https://www.republika.co.id/berita/pendidikan/eduaction/ p3mk3z428/mahfud-md-guru-dianiaya-siswa-karena-runtuhnya-moral).

Melihat adanya fenomena di atas, pendidikan yang mempunyai misi untuk menjadikan peserta didiknya memiliki etika yang baik dipertanyakan. Untuk itu perbaikan konsep pendidikan bisa dilakukan sebagai salah satu langkah awal untuk memperbaiki pendidikan kita. Salah satu tokoh pendidikan abad pertengahan yang mempunyai pemikiran pendidikan yang mencoba memberikan solusi mengenai bagaimana menciptakan pendidikan yang tidak hanya berorientasi pada dunia saja, akan tetapi juga berorientasi akhirat adalah al-Zarnuji dengan karyanya yang cukup monumental yaitu kitab Ta'lim al-Muta'allim, yang mana karya beliau telah banyak dikaji oleh para pelajar khususnya mereka yang belajar di pondok pesantren. Bahkan kepopuleran kitab Ta'lim al-Muta'allim ini juga diakui oleh ilmuwan Barat dan Timur. Selanjutnya dalam makalah ini penulis akan mencoba memaparkan berkaitan dengan biografi alZarnuji, pemikiran pendidikannya, dan relevansi pemikiran pendidikannya di era modern ini.

\section{B. METODE PENELITIAN}

Dalam penelitian ini jenis penelitian yang digunakan adalah penelitian kepustakaan atau library research dengan menggunakan teknik studi dokumentasi. Hal ini berarti bahwa dalam menjawab rumusan masalah yang ada, penulis mengumpulkan data dari buku-buku, jurnal ilmiah, dan lain sebagainya yang relevan dengan pembahasan. Kemudian dianalisis dengan menggunakan pendekatan reflektif thingking, yaitu kombinasi antara pendekatan induksi dan deduksi. 


\section{HASIL DAN PEMBAHASAN}

\section{Biografi al-Zarnuji}

a. Riwayat Hidup al-Zarnuji

Nama lengkap al-Zarnuji adalah Burhan al-Islam al-Zarnuji. Dalam pendapat lain disebutkan bahwa nama lengkapnya adalah Burhan al-Din al-Zarnuji. Nama akhirnya dinisbatkan dari daerah tempat dimana Ia berasal, yakni Zarnuj, yang kemudian melekat sebagai nama panggilannya (Suyudi, 2014: 220). Zarnuj masuk dalam wilayah Irak. Akan tetapi, bisa jadi, kota itu di masa sekarang masuk ke dalam wilayah Turkistan (Afganistan) (As'ad, 2007: ii).

Dikalangan para ulama belum ada kepastian berkaitan dengan tempat dan tanggal kelahiran beliau. Berkaitan dengan kelahiran beliau diperkirakan lahir pada sekitar tahun $570 \mathrm{H}$. Sedangkan berkaitan dengan wafatnya beliau terdapat perbedaan yaitu ada yang mengatakan wafat pada tahun $591 \mathrm{H}$, dan ada juga yang mengatakan wafat sekitar tahun $620 \mathrm{H}$. Menurut penjelasan Plessner, bahwasanya al-Zarnuji telah menyusun kitab Ta'lim al-Muta'allim sekitar setelah tahun $593 \mathrm{H}$, perkiraan tersebut didasarkan pada adanya fakta bahwa beliau banyak mengutip pendapat dari gurunya, dan sebagian guru beliau ditulis dalam kitab Ta'lim alMuta'allim meninggal pada akhir abad ke 6 H (Iqbal, 2015: 371).

\section{b. Latar Belakang Pendidikan al-Zarnuji}

Adapun latar belakang pendidikan al-Zarnuji, beliau menuntut ilmu di Bukhara dan Sar Khan, yaitu sebuah kota yang menjadi pusat kegiatan keilmuan dan pengajaran. Masjid yang berada di kedua kota tersebut dijadikan sebagai lembaga pendidikan yang diasuh oleh Burhanudin alMarghinani, Syamsuddin Abd. Al-Wadjdi, Muhammad bin Muhammad al-Abd asSattar al-Amidi. Diantara guru-guru beliau diantaranya sebagai berikut: Imam Burhan al-Din Ali Bin Abi Bakr al-Farghinani alMarghinani, Imam Fakr al-Islam Hasan bin Mansur al-Farghani Khadikan, Imam Zahir al-Din al-Hasan bin Ali al-Marghinani, Imam Fakr al-Din al-Khasani, dan Imam rukn al-Din Muhammad bin Abi Bakr Imam Khwarzade. Selain itu, al-Zarnuji juga belajar dari ulama'-ulama' lain seperti Ali bin Abi Bikr bin Abdul Jalil al-Farghani alMarghinanji alRustami Ruknul Islam Muhammad bin Abi Bakar, Hammad bin Ibrahim, Taruddin al-Hasan bin Mansyur atau Qadhikhan, Rukhnuddin alFarghani, dan al-Imam Sadiduddin al-Shirazi (Iqbal, 2015:372).

Oleh karena itu, berdasarkan keterangan di atas dapat disimpulkan bahwa pemikiran alZarnuji banyak dipengaruhi oleh faham fiqih yang berkembang pada saat itu, sebagaimana faham yang dikembangkan oleh para gurunya, yaitu fiqih dari aliran Hanafiyah. Hal itu bisa dilihat dari banyaknya ulama Hanafiyah yang dikutip oleh al-Zarnuji, termasuk Abu Hanifah sendiri. Ide-ide mazhab yang dianutnya itulah yang kemudian mempengaruhi pemikirannya tentang pendidikan. Selain dikenal sebagai ahli pendidikan beliau juga dikenal sebagai ahli tasawuf, dan sangat memungkinkan juga beliau juga menguasai bidang sastra, fiqih, ilmu kalam, dan lain sebagainya.

Al-Zarnuji hidup pada masa ke-empat dari periode pendidikan dan perkembangan pendidikan Islam, yakni antara tahun 750 - $1250 \mathrm{M}$. Sehingga beliau mewarisi banyak peninggalan yang ditinggalkan oleh para pendahulunya dalam berbagai bidang ilmu pengetahuan. Karena pada masa tersebut, kebudayaan Islam berkembang dengan pesat hal itu bisa terlihat dari munculnya berbagai lembaga pendidikan, mulai dari tingkat perguruan tinggi 
diantaranya Madrasah Nizamiyah, Madrasah an-Nuriyah al-Kubra, dan Madrasah alMutansiriyah (Suwito \& Asy, 2003: 187).

c. Hasil Karya al-Zarnuji

Adapun hasil karya al-Zarnuji tidak diketahui secara pasti berapa jumlah kitab yang telah ditulisnya, yang diketahui hanya kitab Ta'lim alMuta'allim yang dapat kita jumpai sampai sekarang ini. Persoalan apakah beliau hanya menulis satu kitab saja, ataukah menulis kitab-kitab yang lainnya tidak ditemukan informasi yang melaporkan akan hal itu, akan tetapi, ada indikasi bahwa al-Zarnuji menulis kitab lain namun sudah musnah karena masuk sebagai yang termusnahkan akibat dari tragedi sejarah. Sejarah menyebutkan tokoh Jengis Khan dan pasukannya selama 5 tahun $(1220-1225 \mathrm{H} / 1617-1622 \mathrm{H})$ menaklukkan dan juga menghancurkan Persia timur. Yang masa pada masa itu ada kemungkinan karya al-Zarnuji yang lainnya ikut musnah kecuali kitab Ta'lim al-Muta'allim (Iqbal, 2015: 376).

\section{Pemikiran Pendidikan al-Zarnuji}

Dalam kitab Ta'lim al-Muta'allim terdapat beberapa konsep pemikiran pendidikan yang telah dirumuskan oleh al-Zarnuji, diantara komponen konsep pemikiran pendidikan yang dirumuskan beliau antara lain sebagai berikut:

a. Tujuan Pendidikan

Berkaitan dengan tujuan pendidikan, al-Zarnuji mengatakan bahwa tujuan pendidikan adalah untuk mencari keridhaan Allah, memperoleh kebahagiaan di akhirat, berusaha menghilangkan kebodohan pada diri sendiri dan orang lain, mengembangkan dan melestarikan ajaran Islam, serta mensyukuri nikmat Allah. Dalam hubungan ini, al-Zarnuji mengingatkan, agar setiap penuntut ilmu jangan sampai keliru dalam menentukan niat dalam belajar (Iqbal, 2015: 379). Jika melihat tujuan-tujuan pendidikan yang diungkapkan oleh alZarnuji di atas, tujuan pendidikan yang dirumuskannya sebenarnya tidak hanya untuk akhirat (ideal) saja, tetapi juga untuk kehidupan dunia (praktis), dengan syarat bahwa tujuan yang berorientasi pada dunia ini sebagai sarana pendukung tujuan-tujuan keagamaan (Maragustam, 2018: 142).

Jika dilihat dari tujuan pendidikan yang dirumuskan al-Zarnuji di atas, maka menghilangkan kebodohan pada diri sendiri merupakan tujuan-tujuan yang bersifat individual. Sedangkan untuk menghilangkan kebodohan dari orang lain (masyarakat), menghidupkan nilainilai agama serta melestarikan ajaran Islam adalah merupakan tujuan-tujuan sosial. Dari tujuantujuan sosial ini al-Zarnuji melihat bahwa kesalehan dan kecerdasan itu tidak hanya saleh dan cerdas untuk diri sendiri, tetapi juga harus mampu mentransformasikannya dalam kehidupan masyarakat (Maragustam, 2018: 143-144).

b. Pendidik

Pendidik merupakan salah satu unsur terpenting dalam pendidikan. Dalam hal ini, alZarnuji menyatakan dalam kitabnya berkaitan dengan pendidik yaitu sebagai berikut: bahwa dalam memilih seorang pendidik, hendaklah mencari seorang pendidik yang paling alim, yang paling wara' (seseorang yang menjauhkan diri dari dosa, maksiat, dan perkara yang syubhat/ tidak jelas haram atau halalnya), dan lebih berusia (As'ad, 2007: 26).

c. Peserta didik

Unsur penting lainnya dalam pendidikan adalah peserta didik. Ia merupakan obyek yang sekaligus subjek, yang mana apabila tanpa keberadaannya proses pendidikan tidak akan bisa 
berjalan. Dalam hal ini, al-Zarnuji membahas hal yang berkaitan dengan peserta didik lebih menitikberatkan pada kepribadian atau akhlak mulai yang harus dimiliki oleh peserta didik. Diantaranya yaitu peserta didik harus memiliki sifatsifat tawadhu', iffah, tabah, sabar, wara', dan tawakkal. Selain itu, alZarnuji juga menganjurkan dalam menuntut ilmu, hendaknya seorang peserta didik itu mencintai ilmu, menghormati guru, keluarganya, dan antar sesama teman, menghormati kitab dan menjaganya dengan baik, bersungguh-sungguh dalam belajar, konsisten dan ulet dalam menuntut ilmu dan mempunyai cita-cita tinggi dalam belajar (TIM Dosen Fakultas Tarbiyah UIN Maulana Malik Ibrahim Malang, 2009; 224-225).

Seorang peserta didik harus menghormati ilmu, orang yang berilmu dan pendidiknya, hal itu menjadi penting karena apabila melukai hati pendidiknya, dikhawatirkan berkah ilmunya bisa tertutup sehingga sedikit manfaat yang bisa diambilnya. al-Zarnuji dalam kitabnya mengatakan bahwa diantara cara untuk menghormati pendidik diantaranya yaitu: tidak berjalan didepannya, tidak menempati tempat duduknya, tidak memulai mengajaknya bicara kecuali atas izinnya, tidak bicara macam-macam didepannya, tidak menanyakan suatu masalah pada waktu pendidik lelah, memelihara waktu yang sudah ditentukan untuk belajar, tidak mengetuk pintu rumahnya, tetapi sabar menunggu sabar menunggu hingga pendidik itu keluar dari rumahnya, menghormati anak-anaknya dan siapapun yang berkaitan dengannya. Pada prinsipnya, peserta didik harus melakukan hal-hal yang membuat pendidik rela, jangan sampai membuatnya marah, dan mentaati perintahnya yang tidak bertentangan dengan Agama.

Sedangkan dalam menghormati ilmu, al-Zarnuji merumuskan dalam kitabnya bahwa seorang peserta didik hendaknya ketika belajar dalam keadaan suci. Sebab ilmu adalah cahaya, wudhu pun cahaya, maka akan semakin cemerlang lah cahaya ilmu itu dengan wudhu. Selain itu, peserta didik sebaiknya tidak menjulurkan kakinya ke arah kitab, dan seharusnya meletakkan kitab tafsir diatas kitab yang lainnya dengan niat memuliakan, dan tidak meletakkan apapun di atas kitab.

Selain itu, peserta didik hendaknya juga memperhatikan catatannya, yaitu usahakan menulis dengan rapi dan jelas, agar tidak terjadi penyesalan di kemudian hari. Dan sebaiknya tidak menggunakan tinta warna merah. Disamping itu, peserta didik hendaknya tetap hormat, dengan cara tetap memperhatikan secara seksama terhadap ilmu yang disampaikan padanya walaupun telah diulang seribu kali penyampaiannya (TIM Dosen Fakultas Tarbiyah UIN Maulana Malik Ibrahim Malang, 2009: 273-274). Selain itu peserta didik juga harus bersungguhsungguh dalam belajar dan mengulangi pelajarannya secara terus-menerus, hal ini bisa dilakukan pada awal waktu malam dan diakhir malam, yaitu antara maghrib dan isya' dan setelah waktu sahur, karena pada waktu-waktu tersebut terdapat keberkahan Allah. Hal lain yang juga seharusnya dilakukan oleh peserta didik adalah diskusi, karena dalam diskusi selain mengulangi juga bisa menambah ilmu pengetahuan, dalam pelaksanaannya harus dilakukan dengan penuh kesadaran serta menghindari hal-hal yang membawa negatif (As'ad, 2007: 27)

\section{d. Kurikulum}

Berkaitan dengan kurikulum (materi pengajaran), al-Zarnuji merumuskan dalam kitabnya dalam pasal "Hakikat Ilmu" mengatakan bahwa beberapa ilmu yang harus diberikan, antara lain sebagai berikut: pertama, Ilmu Haal, ilmu ini diartikan sebagai ilmu pengetahuan yang diperlukan dalam melaksanakan agama, seperti Ilmu Ushuluddin, dan Ilmu Fiqih. Kedua ilmu ini tidak dapat diabaikan, karena ilmu yang pertama akan membimbing kehidupan dan ruhaninya, 
sedangkan yang kedua akan membimbing perbuatan jasmani dalam melaksanakan tugas amanat agamanya. Kedua, ilmu-ilmu wasilah, misalnya belajar membaca fatihah menjadi wajib, karena fatihah itu sarana terlaksananya kewajiban shalat. Ketiga, ilmu ahwalul qulub, ilmu ini diartikan ilmu pengetahuan tentang kerohanian seperti tawakkal, taubat, takut, dan ridha. Keempat, ilmu pengetahuan tentang kepribadian, misalnya sifat pemurah, bakhil, pengecut, pemberani, sombong, rendah hati, iffah, kikir, dan lain sebagainya. Kelima, ilmu ketabiban, misalnya seperti ilmu tentang kesehatan, obat-obatan, dan penyakit (Madjidi, 1997: 112).

Sedangkan dalam penyusunan kurikulum (materi pelajaran) alZarnuji mengatakan bahwa sebaiknya dimulai dengan pelajaran yang mudah terlebih dahulu (As'ad, 2007:76). Selain itu, alZarnuji memiliki pandangan bahwa kurikulum yang dipelajari harus relevan, yaitu yang sesuai dengan kebutuhan peserta didik. Hal ini berarti, sudah menjadi keharusan dalam penyusunan kurikulum disesuaikan dengan kemampuan peserta didik. Sehingga, permulaan bahan yang diberikan kepada peserta didik adalah yang mudah terlebih dahulu, baru kemudian naik ke level yang lebih sukar. Ini menunjukan, bahwa materi yang diberikan adalah harus sesuai dengan kematangan peserta didik (Suyudi, 2014: 226).

Pandangan al-Zarnuji mengenai kurikulum lebih berpusat dan memprioritaskan Tuhan dan keagamaan sebagai arah utama pendidikan. Hal ini penting dalam Islam, karena pendidikan yang sifatnya antroposentris terkadang mereduksi khazanah pendidikan Islam itu sendiri. Contohnya pola pikir sekuler yang membeda-bedakan ilmu-ilmu esakta dengan ilmu-ilmu keagamaan, sehingga ilmu-ilmu seperti biologi, sosiologi, matematika, informatika, dsb. dirasa jauh dari peran Tuhan dan sentuhan keagamaan. Dalam Ta'lim al-Muta'alim alZarnuji tidak memisahkan wilayah dari dua macam ilmu tersebut tetapi justru menempatkannya sesuai proporsi dan fungsinya, yaitu ilmu yang berkaitan dengan keagamaan sebagai ilmu utama karena sesuai manfaat praktis keislaman, sedangkan ilmu-ilmu eksakta tidak diabaikan, namun tetap digunakan sebagai penunjang ilmu agama agar lebih pragmatis maslahatnya.

e. Metode Pendidikan

Dari segi metode pendidikan yang dimuat al-Zarnuji dalam kitabnya meliputi dua kategori. Pertama, metode yang bersifat etik, dan kedua metode yang bersifat strategi. Metode yang bersifat etik antara lain mencakup niat dalam belajar, sedangkan metode yang bersifat teknik strategi meliputi cara memilih pelajaran, memilih guru, memiliki teman dan langkahlangkah dalam belajar. Berkenaan dengan teknik strategi dalam langkah-langkah belajar, alZarnuji mengemukakannya sebagai berikut:

1) Mengulang dan menghafal

Bagi seorang murid dianjurkan untuk menghafal pelajaran dengan cara mengulangulangnya. Cara seperti ini dapat lebih mempercepat hafal (As'ad, 2007: 97).

2) Memahami dan mencatat

Bagi seorang murid dianjurkan agar serius dalam memahami pelajaran langsung dari sang guru, bisa dengan cara meresapi, memikirkan, serta banyak-banyak mengulang pelajaran. Selain itu, murid juga dianjurkan untuk membuat catatan terhadap pelajarannya setelah dia hafal dan sering diulang-ulang (As'ad, 2007: 77).

3) Diskusi ilmiah

Dalam melakukan kegiatan diskusi ini, pelajar harus melakukannya ke dalam 3 bentuk, yaitu: mudzakaroh, munadhoroh, dan juga mutharahah. Mudzakaroh 
diartikan sebagai tukar pendapat untuk saling melengkapi pengetahuan masingmasing. Munadhoroh adalah saling mengkritisi pendapat masing-masing, serta mutharahah yakni adu pendapat untuk diuji dan dicari mana yang benar (As'ad, 2007: 80). Metode pendidikan yang diajarkan al-Zarnuji menjadi bukti bahwa sejak periode klasik, khazanah pendidikan Islam begitu inklusif dan demokratis. Hal ini dapat dilihat dari keterbukaan dalam metodenya. Muzakarah, munazarah, dan mutharahah menggambarkan bentuk pembelajaran kelas yang sangat interaktif dan terbuka pada kritik dan pendapat antar murid. Tradisi semacam ini perlu direvitalisasi di masa kini, agar suasana kelas tidak pasif setiap proses belajarmengajar.

\section{Relevansi Pemikiran Pendidikan al-Zarnuji pada Pendidikan Modern}

Dari pemikiran pendidikan yang dirumuskan al-Zarnuji banyak hal-hal yang masih relevan untuk diterapkan dalam dunia pendidikan saat ini, meskipun untuk beberapa hal yang lainnya kurang sesuai untuk diterapkan di era sekarang ini. Dalam hal ini penulis membagi relevansi itu ke dalam dua kategori, yaitu secara umummya, dan secara spesifiknya yang bisa dilihat dari komponen-komponen konsep pendidikan yang dirumuskan oleh al-Zarnuji. Secara umumnya relevansi itu bisa dilihat dari adanya usaha untuk menghidupkan kembali nilai-nilai etika, moral dalam proses pendidikan dan menjadikannya sebagai landasan utama dalam pembentukan akhlak, membuat suasana religius, dan membiasakan akhlak yang baik dalam setiap kegiatan belajar mengajar untuk bisa sampai pada cita-cita keseimbangan dunia dan akhirat. Sedangkan secara spesifiknya relevansi itu bisa dilihat dari komponen-komponen konsep pemikiran pendidikannya, yaitu sebagai berikut:

a. Tujuan Pendidikan

Tujuan pendidikan sebagaimana yang dirumuskan al-Zarnuji yaitu untuk mendapatkan ridha Allah, kebahagiaan di akhirat, berusaha menghilangkan kebodohan terhadap diri sendiri dan orang lain, mengembangkan dan melestarikan ajaran Islam, serta mensyukuri nikmat Allah. Hal tersebut relevan dengan Pendidikan di era modern ini, hal itu bisa dilihat dari adanya kesesuaian dengan tujuan pendidikan Nasional sebagaimana yang tercantum dalam UndangUndang Sisdiknas tahun 2003 pasal II tentang dasar, fungsi, dan tujuan pendidikan yang mengatakan bahwa:

Pendidikan Nasional berfungsi mengembangkan kemampuan dan membentuk watak serta peradaban bangsa yang bermartabat dalam rangka mencerdaskan kehidupan bangsa, bertujuan untuk mengembangkan potensi peserta didik agar menjadi manusia yang beriman dan bertaqwa kepada Tuhan Yang Maha Esa, Berakhlak mulia, sehat, berilmu, cakap, kreatif, mandiri. Dan menjadi warga yang demokratis dan bertanggungjawab" (Undang-Undang No. 20 Tahun 2003 tentang Sistem Pendidikan Nasional Bab 2 Pasal $3)$.

Dalam dunia Pendidikan untuk bisa sampai pada terwujudnya tujuan Pendidikan sebagaimana yang dirumuskan oleh al-Zarnuji dan juga Undang-Undang Sisdiknas tahun 2003 pasal II bisa dilihat dari upaya pemerintah melalui adanya program pendidikan karakter. Dalam Undang-Undang Sisdiknas tahun 2003 pasal II, pasal tersebut sebagai dasar dalam pengembangan pendidikan karakter untuk pembentukan karakter manusia khususnya generasi muda. 
Lingkungan sekolah menciptakan adanya pendidikan karakter dengan tujuan untuk membantu siswa dalam perkembangan etika, tanggung jawab melalui model, dan pengajaran karakter yang baik melalui nilai-nilai universal. Nilai-nilai karakter inilah yang kemudian harus ditanamkan kepada siswa sehingga mereka mampu menerapkan dalam kehidupannya baik di keluarga, sekolah, masyarakat, dan negara sehingga dapat memberikan kontribusi yang positif kepada lingkungannya. Selain itu, pendidikan karakter mempunyai tujuan dalam rangka untuk meningkatkan mutu penyelenggaraan serta hasil pendidikan di sekolah yang bertujuan untuk mengarah pada pencapaian pembentukan karakter dan akhlak mulia siswa secara utuh, terpadu, dan seimbang.

b. Pendidik

Pendidik yang dirumuskan oleh al-Zarnuji, yaitu bahwa dalam memilih seorang pendidik, hendaklah mencari seorang pendidik yang paling alim, yang paling wara', dan yang lebih berusia. Hal tersebut relevan jika dikaitkan diera modern ini hal itu bisa dilihat dari salah satu Standar Kompetensi Guru, yaitu kompetensi kepribadian, yaitu suatu kemampuan yang harus dimiliki oleh seorang pendidik berkaitan dengan kemampuan kepribadian yang mantap, berakhlak mulia, arif, dan berwibawa serta menjadi teladan bagi peserta didik (Wiyani \& Barnawi, 2016:104). Selain itu, Soejono sebagaimana yang dikutip Ahmad Tafsir menyatakan bahwa syarat seorang guru adalah sebagai berikut: pertama, tentang kemampuan mengajar, ia harus ahli, hal ini menjadi penting, karena dengan pengetahuannya diharapkan ia akan lebih berkemampuan mewujudkan penyelenggaraan Pendidikan bagi peserta didiknya. Kedua, Harus berkesusilaan, hal ini menjadi penting dimiliki dalam menjalankan tugas-tugas mendidik selain mengajar. Bagaimana mungkin seorang pendidik akan memberikan contoh-contoh kebaikan bila ia sendiri tidak baik perangainya. Ketiga, tentang umur, harus sudah dewasa, seorang guru dalam melaksanakan tugasnya harus dilakukan secara bertanggungjawab. Itu hanya dapat dilakukan oleh orang yang telah dewasa, oleh karenanya anak-anak tidak dapat dimintai pertanggungjawaban (Tafsir, 2012:127-128).

Selain itu menurut Syafaruddin dan Irwan Nasution sebagaimana dikutip Halid Hanafi dkk., seorang pendidik juga diharuskan memiliki pengetahuan dan juga wawasan yang luas dalam bidang keilmuannya, serta memiliki karakter kepribadian yang membuatnya dihargai, dibanggakan, dan di terima oleh peserta didik (Hanafi, 2015: 145).

Pribadi guru memiliki peran yang sangat besar terhadap keberhasilan pendidikan, khususnya dalam kegiatan pembelajaran. Pribadi guru juga sangat berperan dalam membentuk pribadi peserta didik. Kompetensi kepribadian memiliki pengaruh yang besar terhadap pertumbuhan dan perkembangan pribadi para peserta didik. oleh Karena itu, diperlukan sosok guru kompeten, bertanggung jawab, terampil, dan berdedikasi tinggi. Secara umum bisa dikatakan guru mempunyai tugas dan tanggungjawab untuk mengajak orang lain berbuat baik.

c. Peserta didik

Dari pemikiran al-Zarnuji mengenai peserta didik, relevan jika disesuaikan dengan era modern sekarang ini, hal ini bisa dilihat dari adanya kesesuaian dengan Undang-undang nomor 23 Tahun 2003 tentang Sistem Pendidikan Nasional bagian ketiga Bab V pasal 12 bahwa "peserta didik mempunyai kewajiban untuk menjaga normanorma pendidikan untuk menjamin keberlangsungan proses dan keberhasilan pendidikan." (Undang-Undang No. 20 Tahun 2003 tentang Sistem Pendidikan Nasional Bab 5 Pasal 12). Norma-norma tersebut jika dilihat dari 
pemikiran al-zarnuji ini diantaranya peserta didik harus mempunyai akhlak yang baik, mencintai ilmu, menghormati guru, keluarganya, dan antar sesama teman, menghormati kitab dan menjaganya dengan baik, bersungguh-sungguh dalam belajar, konsisten dan ulet dalam menuntut ilmu dan mempunyai cita-cita tinggi dalam belajar, disiplin dalam belajar, tidak mengotori kitab, tidak meletakkan buku atau kitab di sembarang tempat, juga niat dan kesungguhan dalam mencari ilmu, menulis dengan rapi dan jelas, tidak menggunakan tinta warna merah, peserta didik hendaknya tetap hormat, dengan cara tetap memperhatikan secara seksama terhadap ilmu yang disampaikan padanya walaupun telah diulang seribu kali penyampaiannya. peserta didik juga harus bersungguh-sungguh dalam belajar dan mengulangi pelajarannya secara terusmenerus.

Merujuk kepada keseluruhan hal yang harus dilakukan oleh peserta didik sebagaimana penjelasan di atas, kesemuanya dianjurkan untuk dilakukan oleh peserta didik. Hal ini menjadi penting agar nantinya peserta didik dalam proses pendidikan itu bisa mencapai keberhasilan dari proses pendidikan itu sendiri.

d. Kurikulum

Konsep kurikulum sebagaimana yang dirumuskan oleh al-Zarnuji bahwa ilmu yang harus dipelajari adalah ilmu yang berkaitan dengan keagamaan sebagai ilmu utamanya, ilmu yang berkaitan dengan kerohanian, dan akhlak, serta ilmu-ilmu umum/ eksakta. Sedangkan dalam penyusunannya tetap harus disesuaikan dengan kebutuhan peserta didik. Sehingga, permulaan bahan yang diberikan kepada peserta didik adalah yang mudah terlebih dahulu, baru kemudian naik ke level yang lebih sukar.

Hal tersebut relevan jika dikaitkan dengan era modern sekarang ini, hal tersebut bisa dilihat dari pendapatnya al-Syaibani sebagaimana yang dikutip oleh Moh. Haitami Salim \& Syamsul Kurniawan mengatakan bahwa landasan dasar kurikulum khususnya dalam Pendidikan Islam diantaranya sebagai berikut: dasar agama, dasar ini dijadikan sebagai target tertinggi dalam kurikulum. Tentunya yang dijadikan landasan dasar dalam hal ini adalah al-Qur'an, al-Sunnah, dan lain sebagainya. Selain itu, terdapat pula dasar psikologis, yaitu dalam perumusan kurikulum harus disesuaikan juga dengan ciri-ciri perkembangan psikis peserta didik, sesuai dengan tahap kematangan dan bakatnya, serta kemampuan berpikir dari peserta didik (Salim \& Kurniawan, 2012: 203).

Sebagai contoh, khususnya dalam Pendidikan Islam pada satuan Pendidikan MTs, atau MA mata pelajaran yang diajarkan dalam proses pembelajarannya itu diantaranya ada tauhid, fikih, akhlak, serta ilmu umum yang lainnya. Sudah seharusnya dalam kurikulum Pendidikan Islam dasar-dasar sebagaimana yang disebutkan di atas dijadikan sebagai landasannya, sehingga nantinya kurikulum Pendidikan Islam ini bisa sampai pada tujuan yang diharapkan.

e. Metode Pendidikan

Berdasarkan beberapa pemikiran al-Zarnuji mengenai metode Pendidikan, beberapa masih relevan jika disesuaikan dengan era modern ini. Misalnya saja metode menghafal, dimana dalam metode menghafal ini digunakan untuk memahami sesuatu dengan cara dibaca atau diucapkan berulang-ulang sampai hafal. Teknik ini disebut juga dengan teknik memorisasi, yang diartikan sebagai Teknik dalam menyimpan data serta informasi pengetahuan yang diperoleh dalam otak anak. Metode ini merupakan metode paling lazim yang digunakan dalam mencari ilmu. Pola yang paling umum dalam Teknik ini adalah transfer ilmu pengetahuan yang 
sebanyak-banyaknya dari guru kepada siswa. Yaitu seperti "guru berbicara, murid mendengar", guru menjelaskan kemudian murid mencatat."

Sebagai contohnya metode ini digunakan dalam pelajaran Fiqih misalnya saja pada materi tentang bacaan sholat, syarat dan rukun dari sholat, serta hal-hal yang membatalkan sholat. Selain itu, dalam pelajaran Matematika metode ini digunakan untuk menghafalkan rumus-rumus, sebab apabila tidak hafal terhadap rumus dalam pengerjaannya bisa dipastikan tidak akan bisa mengerjakan soal tersebut dengan tepat (Muliawan, 2016: 103-104).

Selain itu, metode diskusi juga relevan jika disesuaikan dengan era sekarang ini, karena dalam diskusi menekankan aktivitas belajar melalui interaksi komunikasi antara siswa satu dengan siswa yang lainnya dalam membahas satu tema atau topik tertentu untuk nantinya diperoleh suatu kesimpulan. Dalam pelaksanaan metode diskusi juga memerlukan bantuan dari metode-metode yang lainnya misalnya seperti metode ceramah dan juga tanya jawab.

Dalam pelaksanaannya, metode diskusi ini lebih menitikberatkan kepada kemampuan siswa dalam menuangkan gagasannya secara lisan. Yang kemudian melalui metode ini dapat membantu siswa meningkatkan keaktifan dalam pelajaran dengan memberikan kesempatan kepada siswa menyuarakan pendapatnya, membantu siswa dalam mengembangkan pemahaman yang lebih baik dengan cara memberikan kesempatan untuk menyatakan pikiran mereka, dan membantu siswa untuk meningkatkan kecakapan berkomunikasinya (Said \& Budimanjaya, 2017: 37-38).

Metode diskusi ini bisa diterapkan pada jenjang SD kelas tinggi, SMP, serta SMA. Pada umumnya diskusi dilakukan secara kelompok. Metode diskusi ini merupakan salah satu cara belajar aktif yang bisa dijadikan sebagai salah satu solusi untuk menghindari kebosanan siswa dalam proses pembelajaran, diantaranya bisa dilakukan melalui pendekatan inkuiri, yaitu cara belajar-mengajar yang dimaksudkan untuk mengembangkan keterampilan guna memecahkan masalah dengan menggunakan pola berpikir kritis.

\section{KESIMPULAN}

Al-Zarnuji merupakan tokoh pendidikan yang diperkirakan lahir pada tahun $570 \mathrm{H}$, dan meninggal pada tahun $620 \mathrm{H}$. Beliau juga dikenal sebagai ahli tasawuf, sastra, fiqih, ilmu kalam dan lain-lain. Beliau hidup antara tahun 750-1250 M yaitu pada masa kejayaan peradaban Islam, akan tetapi karya beliau yang masih ada sampai sekarang hanya kitab Ta'lim al-Muta'allim, bisa jadi beliau juga punya karya-karya yang lain akan tetapi hilang bersamaan dengan adanya penyerangan oleh bangsa Mongol.

Pemikiran pendidikan yang dirumuskan oleh al-Zarnuji diantaranya yaitu berkaitan dengan tujuan pendidikan, yaitu untuk mendapatkan ridha Allah, kebahagiaan akhirat, menghilangkan kebodohan dalam dirinya, dan orang lain, serta menjaga kelestarian agama. Guru diharapkan lebih wara', alim, dan berumur. Peserta didik diharuskan memiliki akhlak yang baik, mencintai ilmu, menghormati guru, keluarganya, dan antar sesama teman, menghormati kitab dan menjaganya dengan baik, bersungguh-sungguh dalam belajar, konsisten dan ulet serta mempunyai cita-cita tinggi. Berkaitan dengan kurikulum terdiri dari ilmu haal, ilmu wasilah, ahwalul qulub, ilmu pengetahuan tentang kepribadian, serta ilmu ketabiban. Dalam penyusunannya disesuaikan dengan kemampuan peserta didik, Dari segi metode Pendidikan diantaranya yaitu menghafal, mencatat, dan diskusi. 
Relevansi Pemikiran Pendidikan al-Zarnuji di Era Modern, bisa dilihat dari hal berikut: 1) tujuan Pendidikan, relevansi itu bisa dilihat dari adanya kesesuaian untuk menjadikan akhlak sebagai muara atau tujuan akhir dari proses Pendidikan. 2) pendidik, relevansi itu bisa dilihat dari adanya kesesuaian bahwa seorang pendidik itu harus mempunyai kepribadian yang baik, mempunyai pengetahuan, dan juga haruslah dewasa. 3) peserta didik, relevansi itu bisa dilihat dari adanya kesesuaian bahwa peserta didik diharuskan mempunyai akhlak yang baik berkaitan dengan dirinya, guru, teman, serta ilmu. 4) kurikulum, relevansi itu bisa dilihat dari adanya kesesuaian bahwa dalam komponen kurikulum berisi materi ilmu agama, ilmu kerohanian, dan akhlak, serta ilmu-ilmu umum/ eksakta. Sedangkan dalam penyusunannya tetap harus disesuaikan dengan kebutuhan peserta didik. 5) metode pendidikan, relevansi itu bisa dilihat dari adanya kesesuaian bahwa dalam pendidikan metode menghafal dan diskusi digunakan dalam pembelajaran. Metode menghafal dipergunakan untuk menghafal konsepkonsep dasar, sedangkan diskusi lebih digunakan untuk pendidikan yang menuntut peserta didiknya aktif.

\section{DAFTAR PUSTAKA}

As'ad, A. (2007). Terjemah Ta'limul Muta'allim: Bimbingan Bagi Penuntut Ilmu Pengetahuan. Kudus: Menara Kudus.

Hanafi, H., dkk. ,. (2015). Ilmu Pendidikan Islam. Yogyakarta: Pustaka Pelajar.

Iqbal, A. M. (2015). Pemikiran Pendidikan Islam. Yogyakarta: Pustaka Pelajar.

Madjidi, B. (1997). Konsep Kependidikan Para Filosof Muslim. Yogyakarta: Al-Amin.

Maragustam. (2018). Filsafat Pendidikan Islam Menuju Pembentukan Karakter. Yogyakarta: Pascasarjana FITK UIN Sunan Kalijaga Yogyakarta.

Muliawan, J. U. (2016). 45 Model Pembelajaran Spektakuler. Yogyakarta: Arruz Media.

Pemerintah Indonesia, Undang-Undang No. 20 Tahun 2003 tentang Sistem Pendidikan Nasional Bab 2 Pasal 3. Lembaran Negara RI Tahun 2003, No 20, Jakarta: Sekretariat Negara, 2003.

Ratna Puspita, "Mahfud MD: Guru Dianiaya Siswa Karena Runtuhnya Moral", https://www.republika.co.id/berita/pendidikan/eduaction/p3mk3z428/mahfud-md-gurudianiaya-siswa-karena-runtuhnya-moral), di akses tanggal 13 Oktober 2019.

Said, A., \& Budimanjaya, A. (2017). 95 Strategi Mengajar Multiple Intelligences. Jakarta: Kencana.

Salim, M. H., \& Kurniawan, S. (2012). Studi Ilmu Pendidikan Islam. Yogyakarta: Arruz Media.

Suwito, \& Asy, F. (2003). Sejarah Pemikiran Para Tokoh Pendidikan. Bandung: Angkasa.

Suyudi. (2014). Filsafat Pendidikan Islam: Kajian Filsafat dan Pemikiran Pendidikan Islam. Yogyakarta: Belukar.

Tafsir, A. (2012). Ilmu Pendidikan Islam. Bandung: Remaja Rosdakarya.

TIM Dosen Fakultas Tarbiyah UIN Maulana Malik Ibrahim Malang. (2009). Pendidikan Islam dari Paradigma Klasik Hingga Kontemporer. Malang: UIN Malang Press.

Wiyani, N. A., \& Barnawi. (2016). Ilmu Pendidikan Islam. Yogyakarta: Arruz Media. 